\title{
Analysis of Student Conception of Atomic Structure at the State SMA in Palu
}

\section{*Gavrila \& Suherman}

Pendidikan Kimia/FKIP - Universitas Tadulako, Palu - Indonesia 94119

Received 19 March 2020, Revised 22 April 2020, Accepted 26 May 2020

doi: 10.22487/j24775185.2020.v9.i2.pp111-117

\begin{abstract}
This study aimed to analyze student's knowledge (percent) for who know concept (KC), misconception (MC) and do not know concept (DKC) on the subject of atomic structure at the state SMA in Palu. Sample of this study were students of SMAN Model Terpadu Madani, SMAN 3, and SMAN 9. Data were obtained through tracer tests of students' conception in the form of multiple-choice consisted of 20 items accompanied by CRI (Certainty of Response Index) which was given to students to determine students' conceptions. Results of the study showed that the percentage of $K C, M C$, and DKC at SMAN Madani Model Palu were 65.6, 11.3, and 23.2\% respectively, while at SMAN 3 Palu were 46.0, 15.1, and $38.9 \%$ respectively, and at SMAN 9 Palu were 5.9, 72.6, and 21.5\% respectively.
\end{abstract}

Keywords: Student conception, CRI (certainty of response index), high school, chemistry

\section{Pendahuluan}

Ilmu kimia merupakan pelajaran yang banyak memiliki materi yang bersifat abstrak (Gabel, 2009). Pada saat siswa mempelajari kimia di SMA, konsepsi siswa tentang partikel-partikel materi terkait orbital atom, orbital molekul, dan hibridisasi cenderung salah karena semua partikel materi bersifat abstrak atau terkesan abstrak dan mikroskopik (Mursiti dkk., 2006). Selain itu banyak siswa mengalami kesulitan dalam memahami materi abstrak dalam bidang kimia, dan ini berkorelasi dengan tingkat pemahamannya. Kesulitan memahami materi kimia terjadi tidak hanya untuk siswa sekolah menengah, tetapi juga untuk mahasiswa. Materi tersebut meliputi konsep pengantar, struktur atom, ikatan kimia, ekuilibrium kimia dan reaksi kimia, elektrokimia, alkena organik, oksidasi dan reduksi, asam basa dan larutan (Horton, 2007).

Siswa yang mengalami kesulitan dalam memahami konsep-konsep pada pelajaran kimia terkadang membuat penafsiran sendiri terhadap konsep yang dipelajari sebagai suatu upaya untuk mengatasi kesulitan belajarnya. Namun, hasil tafsiran siswa terhadap konsep Berdasar pemahamannya terhadap sebuah konsep, sejumlah orang dapat dikelompokkan menjadi tiga yaitu orang yaitu orang yang tahu konsep (TK), tidak tahu konsep (TTK), dan miskonsepsi (MK). Jika konsepsi seseorang terhadap suatu konsep sama dengan konsepsi para ilmuwan, maka dikatakan orang tersebut mempunyai konsepsi yang benar. Sebaliknya, seseorang yang memiliki ide atau gagasan tentang konsep yang berbeda dengan konsep yang disepakati dan dianggap benar para ahli maka orang itu dinyatakan miskonsepsi (Ibrahim, 2012). Fenomena miskonsepsi pada siswa, mahasiswa, guru atau siapa pun tidak boleh dibiarkan karena miskonsepsi merupakan penghambat untuk memahami konsep-konsep berikutnya (Afadil \& Diah, 2018).

Sebelum diperbaiki, miskonsepsi harus terlebih dahulu diidentifikasi. Identifikasi miskonsepsi diperlukan dalam mengembangkan strategi untuk membentuk pengetahuan konsep yang benar pada masing-masing siswa maupun mahasiswa (Kurniasih, 2017). Salah satu materi kimia yang banyak direspon secara miskonsepsi oleh siswa adalah struktur atom yang dijadikan kajian dalam penelitian ini. Pilihan kajian materi ini didasarkan kepada hasil-hasil penelitian terdahulu bahwa konsep struktur atom sering dipahami siswa secara miskonsepsi (Coll \& Taylor, 2002; Al-balushi dkk., 2012; Harrison \& Treagust, 1996; Trindade dkk., 2002), padahal struktur atom adalah salah satu topik yang paling penting dalam pendidikan kimia. Penelitian lain menunjukan miskonsepsi dapat terjadi karena didasarkan atas hubungan pengetahuan prasyarat dan pengetahuan ikatan kima pada siswa dalam materi ikatan kimia. Pengetahuan prasyarat yang menjadi pangkal penyebab miskonsepsi adalah penentuan teori-teori atom, sifat-sifat unsur dalam tabel periodik unsur, kestabilan unsur, konfigurasi

${ }^{*}$ Correspondence:

Gavrila

e-mail: gavrilamaygiestahm@gmail.com

(c) 2020 the Author(s) retain the copyright of this article. This article is published under the terms of the Creative Commons Attribution License 4.0, which permits unrestricted non-commercial use, distribution, and reproduction in any medium, provided the original work is properly cited. 
elektron, dan struktur lewis (Noviani \& Istiyadji, 2017).

Berdasarkan data observasi rata-rata nilai ulangan harian siswa kelas X pada materi struktur atom di SMAN Model Terpadu Madani, SMAN 3 Palu dan SMAN 9 Palu berturut-turut adalah sebagai berikut: $60.7 ; 74.3$; dan 92.6. Nilai siswa pada ketiga sekolah berbeda-beda dengan selisih yang cukup jauh.

Kesalahan siswa dalam menjawab soal, tidak sepenuhnya karena siswa miskonsepsi. Tidak tahu konsep bisa juga menjadi penyebabnya. salah satu metode yang dapat digunakan untuk mendeteksi konsepsi siswa adalah CRI (Jannah dkk., 2016). CRI merupakan metode yang digunakan untuk mengukur tingkat keyakinan/kepastian responden dalam menjawab setiap pertanyaan (soal) yang diberikan. CRI biasanya didasarkan pada suatu skala dan diberikan bersamaan dengan setiap jawaban suatu soal (Hasan dkk., 1999).

Uraian di atas mengindikasikan pentingnya menganalisis konsepsi siswa pada materi-materi kimia khususnya pada materi struktur atom. Salah satu metode yang dapat digunakan untuk menganalisis konsepsi pada materi struktur atom adalah metode certainty of response index (CRI). Sehingga konsepsi dalam penelitian ini terbagi dalam 3 kriteria yaitu tahu konsep (TK), miskonsepsi (MK) dan tidak tahu konsep (TTK).

Tulisan ini dimaksudkan untuk mendeskripsikan tentang konsepsi siswa tentang materi struktur atom di SMAN Kota Palu.

\section{Metode}

Jenis penelitian yang dilakukan merupakan jenis penelitian deskriptif kuantitatif yang menggunakan teknik pengukuran berupa tes yang disertai dengan CRI. Populasi dalam penelitian ini adalah seluruh siswa SMA Negeri di Kota Palu yang telah mempelajari materi struktur atom. Sedangkan sampel yang dipilih yaitu 3 SMA Negeri di Kota Palu diantaranya adalah SMA Negeri 9 Palu Kelas XI MIA 1, SMA Negeri Model Terpadu Madani Palu Kelas XI MIA 6 dan SMA Negeri 3 Palu kelas XI MIA 3. Penentuan kelas dari ketiga sekolah adalah secara random.

Teknik pengambilan sampel dengan cara melihat purposive sampling. Alasan memilih ketiga sekolah di atas karena berdasarkan kategori peringkat yang mewakili sekolah-sekolah tingkat menengah atas di Kota Palu. Kategori yang dimaksudkan yaitu kategori peringkat tinggi, kategori peringkat sedang, dan kategori peringkat rendah. Serta pertimbangan lokasi, dimana ketiga sekolah telah mewakili 3 kecamatan yang berada di wilayah kota Palu.

Data dalam penelitian ini diperoleh melalui tes pelacak konsepsi tentang struktur atom berbentuk pilihan ganda disertai dengan CRI berisikan tingkat keyakinan dalam menjawab soal yang diberikan kepada siswa untuk menentukan perbedaan siswa yang tahu konsep (TK), tidak tahu konsep (TTK) dan miskonsepsi (MK) pada hasil tes. Tingkat keyakinan siswa dalam menjawab pertanyaan yang disarankan adalah sebagai berikut (Çetingül \& Geban, 2005):

[0] (Totally Guessed Answer): Jika menjawab soal $100 \%$ ditebak

[1] (Almost Guess): Jika dalam menjawab soal presentase unsur tebakan antara 75\%-99\%

[2] (Not Sure): Jika dalam menjawab soal presentase unsur tebakan antara 50\%-74\%

[3] (Sure): Jika dalam menjawab soal presentase unsur tebakan antara 25\%-49\%

[4] (Almost Certain): Jika dalam menjawab soal presentase unsur tebakan antara $1 \%-24 \%$

[5] (Certain): Jika dalam menjawab soal tidak ada unsur tebakan sama sekali (0\%)

Selain identifikasi miskonsepsi yang dilakukan perorangan, identifikasi miskonsepsi juga dapat dilakukan secara berkelompok, misalnya untuk satu kelas. Hal ini dapat dilakukan untuk menentukan konsep mana yang memberikan dampak miskonsepsi paling besar.

Identifikasi miskonsepsi secara berkelompok didasarkan pada rata-rata indeks CRI dari responden yang menjawab benar (CRIB) dan ratarata indeks CRI dari responden yang menjawab salah (CRIS), dan fraksi responden yang menjawab benar (FB). Perhitungan nilai CRIB, CRIS dan FB menggunakan rumus (Nuha \& Sukarmin, 2013):

CRIB $=\frac{\text { Total jumlah CRI dari jawaban benar }}{\text { Jumlah siswa yang menjawab benar }}$

CRIS $=\frac{\text { Total jumlah CRI dari jawaban salah }}{\text { Jumlah siswa yang menjawab salah }}$

FB $=\frac{\text { Jumlah siswa yang menjawab benar }}{\text { total jumlah siswa }}$

\section{Hasil dan Pembahasan}

Hasil penelitian ini diperoleh dari tes pelacak konsepsi siswa. Butir tes pelacak konsepsi siswa pada materi struktur atom telah divalidasi oleh seorang ahli untuk menentukan kategori validitas setiap aspek dalam butir tes tersebut dan telah dinyatakan layak digunakan untuk mengidentifikasi konsepsi siswa. Ada beberapa konsep yang diujikan, yaitu: (1) teori atom, (2) partikel penyusun atom, (3) elektron valensi, (4) nuklida, dan (5) susunan elektron.

\section{Hasil Tes Pendeteksi Konsepsi Siswa SMAN Model Terpadu Madani Palu}

Setelah dilakukan tes untuk mendeteksi konsepsi siswa tentang materi struktur atom yang terdiri dari TK, TTK, dan MK pada masing- 


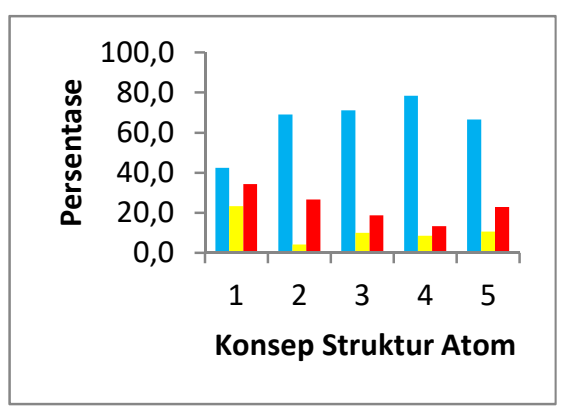

Gambar 1. Perbandingan presentase konsepsi siswa SMAN Model Terpadu Madani tentang materi struktur atom

$$
=\mathrm{TK}: \square=\mathrm{TTK}: \square=\mathrm{MK}
$$

masing konsep, diperoleh hasil yang disajikan pada Gambar 1 dan 2.

Hasil analisis menunjukan pada Gambar 1 konsep yang paling banyak direspon siswa secara miskonsepsi dan tidak tahu konsep adalah konsep pertama yaitu konsep teori atom. Namun siswa cenderung menguasai konsep keempat yaitu nuklida yang membahas tentang isotop, isoton dan isobar. Secara keseluruhan dapat diketahui bahwa dari 5 konsep yang diujikan, semua siswa mengalami miskonsepsi. Secara umum presentase siswa dalam merespon materi struktur atom dapat digambarkan dalam Gambar 2.

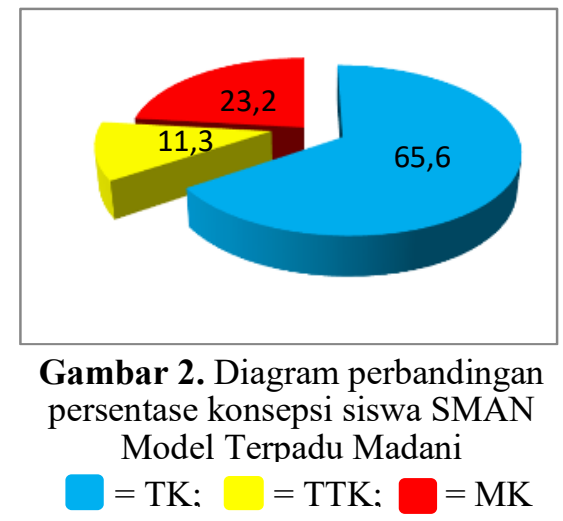

Dari hasil di atas, tampak bahwa konsepsi setiap siswa berbeda-beda. Hal ini telah dinyatakan oleh (Hammer, 1996) bahwa tafsiran perorangan terhadap banyak konsep sangat mungkin berbedabeda. Perbedaan tersebut diperoleh dari respon setiap orang terhadap suatu konsep.
Untuk menetapkan konsep yang diduga paling kuat miskonsepsinya dari 5 konsep yang diujikan kepada siswa maka digunakan identifikasi miskonsepsi klasikal yang didasarkan pada data CRIB, CRIS, dan FB yang disajikan dalam bentuk grafik seperti ditunjukan pada Gambar 3.

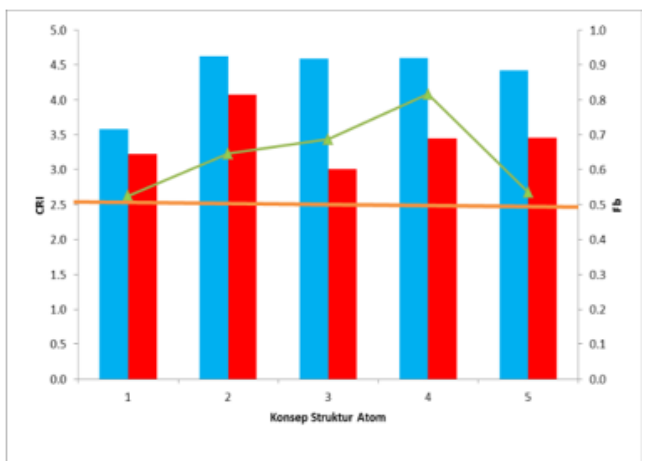

Gambar 3. Perbandingan CRIB, CRIS, dan FB pada setiap konsep struktur atom

$$
\text { - = CRIB } ; \quad-=\text { CRIS; } \quad-\text { FB }
$$


Hasil analisis pada Gambar 3 menunjukan bahwa respon miskonsepsi siswa terhadap 5 konsep yang diujikan tergolong lemah atau tidak berdampak kuat. Karena di peroleh hasil analisis pada semua konsep memiliki nilai CRIS $>2.5$ dan FB $>0.5$. Miskonsepsi yang berdampak kuat terjadi jika $2.5<$ CRIS $\leq 0.5$ (Hasan dkk., 1999).

\section{Hasil Tes Pendeteksi Konsepsi Siswa SMAN 3 Palu}

Setelah dilakukan tes untuk mendeteksi konsepsi siswa yang terdiri dari TK, TTK, dan MK pada materi struktur atom untuk masingmasing konsep, diperoleh hasil yang disajikan pada Gambar 4 dan 5.

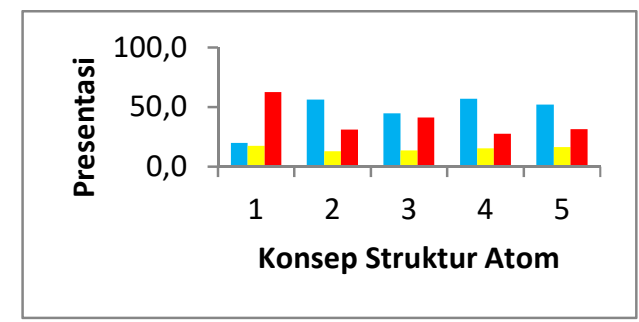

Gambar 4. Perbandingan presentase

konsepsi siswa SMAN 3 Palu tentang materi struktur atom

$$
=\mathrm{TK}: \square=\mathrm{TTK}: \square=\mathrm{MK}
$$

Hasil analisis yang diperoleh berdasarkan Gambar 4 konsep yang paling banyak direspon siswa secara miskonsepsi adalah konsep 1 yaitu konsep teori atom. Namun siswa cenderung menguasai konsep 2 dan 4 yaitu partikel penyusun atom dan nuklida. Relevan dengan SMAN Model
Terpadu Madani dari 5 konsep yang diujikan, semua siswa SMAN 3 Palu mengalami miskonsepsi. Secara umum umum presentase siswa dalam merespon materi struktur atom dapat digambarkan pada Gambar 5.

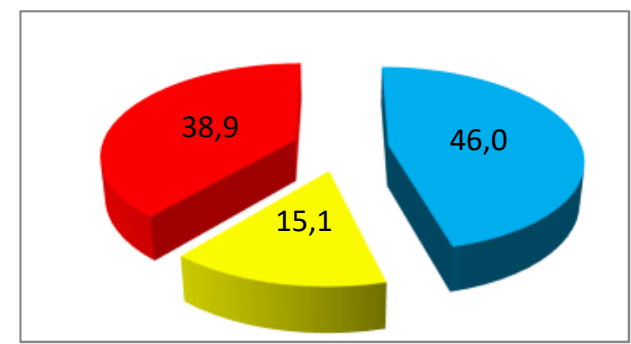

Gambar 5. Diagram perbandingan persentase konsensi siswa SMAN 3 Palu = TK: $\square$ TTK: $\square=\mathrm{MK}$

Untuk menetapkan konsep yang diduga paling kuat miskonsepsinya dari 5 konsep yang diujikan kepada siswa maka digunakan identifikasi miskonsepsi klasikal yang didasarkan pada data CRIB, CRIS, dan FB yang disajikan dalam bentuk grafik seperti ditunjukan pada Gambar 6.

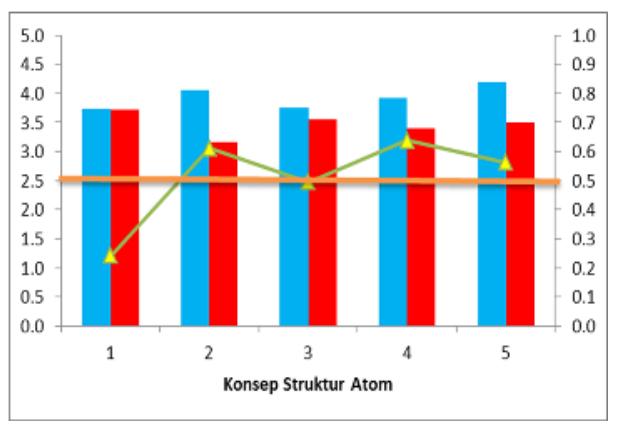

Gambar 6. Perbandingan CRIB, CRIS, dan FB pada setiap konsep struktur atom

$$
\text { - = CRIB; }-=\text { CRIS; } \quad=\text { FB }
$$


Gambar 6 menunjukan bahwa respon miskonsepsi siswa terhadap 5 konsep yang diujikan tergolong lemah atau tidak berdampak kuat. Karena di peroleh hasil analisis pada semua konsep memiliki nilai CRIS $>2.5$ dan FB $>0.5$ kecuali pada konsep 1 dan 3.

\section{Hasil Tes Pendeteksi Konsepsi Siswa SMAN 9 Palu}

Siswa SMAN 9 Kota Palu yang berjumlah 23 orang memiliki nilai rata-rata ulangan harian pada materi struktur atom lebih tinggi dari kedua sekolah yang dijadikan sampel penelitian yaitu 92.6. Hal ini dikarenakan dalam mengerjakan soal siswa dapat melihat buku teks. Setelah dilakukan tes untuk mendeteksi konsepsi siswa pada materi struktur atom yang terdiri dari TK, TTK, dan MK pada masing-masing konsep, maka diperoleh hasil yang disajikan pada Gambar 7 dan 8. 5 konsep yang diujikan, semua siswa mengalami miskonsepsi. Tetapi semua konsep direspon secara dominan TTK. Hal ini disebabkan siswa tidak memahami konsep yang diujikan, dalam hal ini konsep struktur atom. Sesuai dengan pendapat (Suparno, 2005) bahwa rendahnya pemahaman konsep disebabkan adanya pemahaman siswa yang dipengaruhi oleh tafsiran siswa terhadap suatu konsep dan siswa tidak memiliki pengetahuan mendasar terhadap suatu konsep. Secara umum presentase siswa dalam merespon materi struktur atom dapat digambarkan pada Gambar 8.

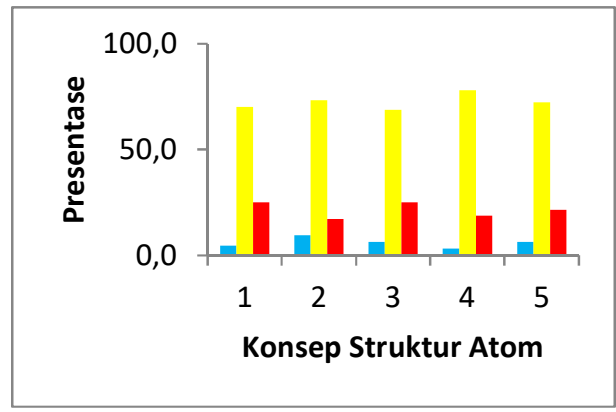

Gambar 7. Perbandingan presentase konsepsi siswa SMAN 9 Palu tentang materi struktur atom

$=\mathrm{TK}: \square=\mathrm{TTK}: \square=\mathrm{MK}$

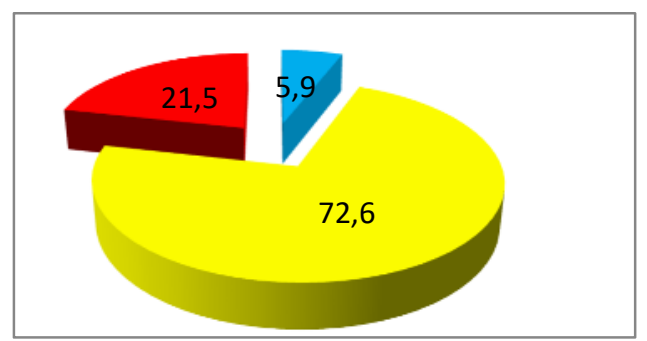

Gambar 8. Diagram perbandingan persentase konsepsi siswa SMAN 9 Palu

$$
=\mathrm{TK}: \square=\mathrm{TTK}: \square=\mathrm{MK}
$$

Persentase siswa yang tidak tahu konsep tergolong tinggi dan sangat berdampak bagi pemahaman konsep struktur atom yang adalah materi dasar pada pembelajaran kimia SMA.

Untuk menetapkan konsep yang diduga paling kuat miskonsepsinya dari 5 konsep yang diujikan kepada siswa maka digunakan identifikasi miskonsepsi klasikal yang didasarkan pada data CRIB, CRIS, dan FB yang disajikan dalam bentuk grafik seperti ditunjukan pada Gambar 9.

Hasil analisis berdasarkan Gambar 9 miskonsepsi tergolong lemah dan cenderung kuat pada kriteria TTK karena hasil analisis menunjukan CRIS $<2.5$ dan FB $<0.5$. Ketiga sekolah yang diberikan tes pelacak konsepsi siswa, menunjukan adanya perbedaan dalam segi merespon konsep.

Berdasarkan Tabel 1, kategori TK didominasi oleh SMAN Model Terpadu Madani. SMAN ini merupakan salah satu SMA favorit di kota Palu yang memiliki kualifikasi dalam penerimaan siswa-siswinya. Dimana ada proses seleksi untuk bisa belajar di sekolah ini. Selain itu, siswa yang lolos tentunya memiliki kemampuan dasar yang 
lebih baik. Hal ini menjadi dorongan atau motivasi bagi siswa untuk bersaing dalam bidang akademik dan non akademik. Menurut penilaian guru siswa aktif dan mudah tanggap, sehingga kemauan siswa untuk belajar tergambar dari sikap antusias mereka dalam proses belajar mengajar khususnya pada materi struktur atom. Ini merupakan salah satu faktor penyebab tingginya kategori TK yang direspon oleh siswa.

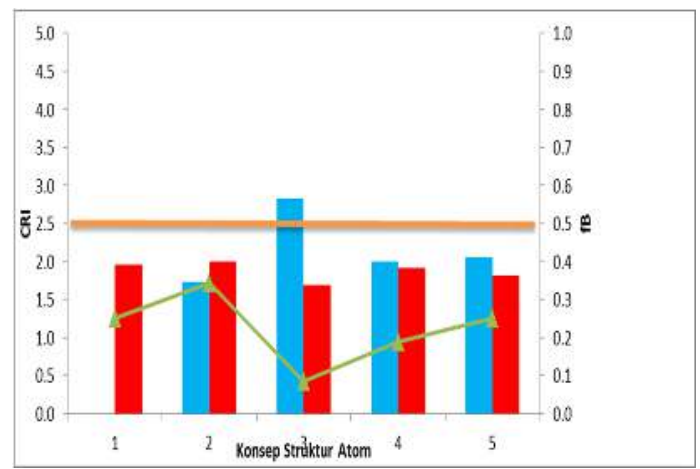

Gambar 9. Perbandingan CRIB, CRIS, dan FB

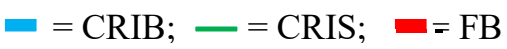

Tabel 1. Persentase konsepsi setiap sekolah

\begin{tabular}{cccc}
\hline \multirow{2}{*}{ Nama Sekolah } & $\begin{array}{c}\text { SMAN Model Terpadu } \\
\text { Madani Palu (\%) }\end{array}$ & $\begin{array}{c}\text { SMAN 3 Palu } \\
(\%)\end{array}$ & $\begin{array}{c}\text { SMAN 9 Palu } \\
(\%)\end{array}$ \\
\hline TK & 65.6 & 46.0 & 5.9 \\
TTK & 11.3 & 15.1 & 7.6 \\
MK & 23.2 & 38.9 & 21.5 \\
\hline
\end{tabular}

Tabel yang disajikan juga menunjukan bahwa kategori MK didominasi oleh SMAN 3 Palu. Beberapa hal yang menjadi penyebab miskonsepsi yaitu siswa, guru, buku teks, konteks dan metode mengajar. Bagi miskonsepsi yang dari siswa, penyebab miskonsepsi yaitu: prakonsepsi, pemikiran humanistik, pemikiran asosiatif siswa, reasoning yang tidak lengkap, intuisi yang salah, perkembangan kognitif siswa, minat siswa, dan kemampuan siswa (Suparno, 2005). Relevan dengan penelitian yang dilakukan sebelumnya (Mentari dkk., 2014; Setiawan dkk., 2017) berupa faktor penyebab terjadinya miskonsepsi pada materi ikatan kimia yang memiliki keterkaitan dengan materi struktur atom yaitu terletak pada kesalahan metode pembelajaran dan konsepsi awal siswa serta sumber belajar (LKS).

Ketiga sekolah merespon materi struktur atom secara miskonsepsi. Tetapi SMAN 9 Palu memiliki presentase MK yang sedikit dibandingkan sekolah lainnya yang dijadikan sampel penelitian. Berdasarkan beberapa penelitian yang telah dilakukan sebelumnya, siswa yang salah dalam menjawab soal belum tentu diakibatkan karena siswa mengalami miskonsepsi, tetapi bisa saja siswa sama sekali tidak tahu konsep. Sehingga siswa SMAN 9 Palu memiliki persentase TTK yang sangat tinggi. Untuk mendukung hasil analisis maka dilakukan wawancara peneliti dengan guru kimia kelas $\mathrm{X}$
SMAN 9 Palu Armin, S.Pd ada beberapa faktor yang menyebabkan hal tersebut, diantaranya adalah: (1) guru baru menerapkan model pembelajaran yang dirujuk kurikulum 2013 sehingga siswa belum terbiasa dengan model pembelajaran yang digunakan dan masih terbiasa dengan metode ceramah.(2) kurangnya penanaman konsep kepada siswa, hal ini terlihat dari cara mengerjakan ulangan harian untuk materi struktur atom yaitu dengan melihat buku teks serta soal ulangan harian harus sama seperti contoh dalam buku teks jika tidak siswa akan kesulitan menjawab soal. (3) kemampuan siswa berbeda-beda dan lebih didominasi oleh siswa yang berkemampuan rendah. (4) siswa tidak memiliki buku pegangan dan rasa ingin tahu siswa sangat rendah.

Siswa yang masih dinyatakan mengalami miskonsepsi maupun tidak tahu konsep harus diupayakan untuk mereduksinya dengan pendekatan yang lebih individualistik. Melalui hasil penelitian ini yaitu analisis konsepsi siswa tentang materi struktur atom di SMAN Kota Palu sudah ditetapkan konsep-konsep yang direspon siswa yang TTK, atau siswa yang tergolong resistensi miskonsepsi kuat/ permanen maupun miskonsepsi lemah. Berdasarkan kondisi di atas maka kiranya dapat ditentukan pola tindakan untuk mengatasi hal tersebut di atas. 


\section{Kesimpulan}

Persentase TK, TTK, dan MK pada SMAN Model Terpadu Madani berturut - turut adalah $65.6 \%, 11.3 \%, 23.2 \%$. SMA N 3 Palu diperoleh hasil persentase TK, TTK, dan MK berturut - turut adalah 46,0\%, 15.1\%, 38.9\%. SMAN 9 Palu diperoleh hasil persentase TK, TTK, dan MK berturut-turut adalah 5.9\%, 72.6\%, $21.5 \%$.

\section{Ucapan Terima Kasih}

Penulis mengucapkan terima kasih kepada Maman, Yuliana, Alamsyah, dan Armin, sebagai guru mata pelajaran kimia serta siswa-siswi di SMA Negeri Model Terpadu Madani Palu, SMAN 3 Palu, dan SMAN 9 Palu serta semua pihak yang banyak membantu penulis dalam menyelesaikan penelitian ini.

\section{Referensi}

Afadil, \& Diah, A. W. M. (2018). Effectiveness of learning materials with science-philosophy oriented to reduce misconception of students on chemistry, Proceeding of The First Indonesian Communication Forum of Teacher Training and Education Faculty Leader International Conference on Education 2017. Amsterdam: Atlantis Press.

Al-balushi, S. M., Ambusaidi, A. K., Al-shuaili, A. H., \& Taylor, N. (2012). Omani twelfth grade students most common misconceptions in chemistry. Science Education International, 3(23), 221-240.

Çetingül, P. İ., \& Geban, Ö. (2005). Understanding of acid-base concept by using conceptual change approach. Hacettepe Üniversitesi Journal of Education, 1(29), 6974.

Coll, R., \& Taylor, N. (2002). Mental models in chemistry: Senior chemistry students mental models of chemical bonding. Chemistry Education: Research and Pratice in Europe, 2(3), 175-184.

Gabel, D. (2009). Improving teaching and learning through chemistry education research: a look to the future. Journal of Chemical Education, 74(4), 548-554.

Hammer, D. (1996). More than misconceptions: multiple perspectives on student knowledge and reasoning, and an appropriate role for education research. American Journal of Physics, 64(10), 1-3

Harrison, A. G., \& Treagust, D. F. (1996). Secondary students' mental models of atoms and molecules: implications for teaching chemistry. Science Education, 80(5), 509534.
Hasan, S., Bagayoko, D., \& Kelley, E. L. (1999). Misconceptions and the certainty of response index (CRI). Physics Education, 5(34), 294299.

Horton, C. Student preconception and misconceptions in chemistry (student alternative conceptions in chemistry). Diakses tanggal 12 Mei 2019, dari http://modeling.asu.edu/modeling/ChemAltConceptions3-09.doc.

Ibrahim, M. (2012). Konsep miskonsepsi dan cara mengatasinya. Surabaya: Unesa University Press.

Kurniasih, M. D. (2017). Analisis miskonsepsi mahasiswa dengan menggunakan certainty of response index (CRI) pada materi anatomi tubuh manusia. Jurnal Pendidikan Sains \& Matematika, 5(1), 1-11

Mentari, L., Suardana, N., \& Subagya, I. W. (2014). Analisis miskonsepsi siswa SMA pada pembelajaran kimia untuk materi larutan penyangga. E-Journal Kimia Visvitalis Universitas Pendidikan Ganesha Jurusan Pendidikan Kimia, 2(1), 78-87.

Jannah, M., Ningsih, P., \& Ratman. (2016). Analisis miskonsepsi siswa kelas XI SMA Negeri 1 Banawa Tengah pada pembelajaran larutan penyangga dengan CRI (certainty of response index). Jurnal Akademika Kimia, 5(2), 85-90.

Mursiti, S., Fardhyanti, D. S., Cahyono, E., \& Sudarmin. (2006). Remediasi miskonsepsi orbital molekul dan hibridisasi melalui pembelajaran interaktif dengan animasi simulasi berbantuan komputer. Indonesian Journal of Chemical Science, 6(1), 104-110.

Noviani, M. W., \& Istiyadji, M. (2017). Miskonsepsi ditinjau dari penguasaan pengetahuan prayarat untuk materi ikatan kimia kelas X. Jurnal Inovasi Pendidikan Sains, 8(1), 63-77.

Nuha, W. U., \& Sukarmin. (2013). Pengembangan software pendeteksi miskonsepsi kimia. Unesa Journal of Chemical Education, 2(3), 85-89.

Setiawan, D., Cahyono, E., \& Kurniawan, C. (2017). Identifikasi dan analisis miskonsepsi pada materi ikatan kimia menggunakan instrumen tes diagnostik three-tier. Journal of Innovative Science Education, 6(2), 197-204.

Suparno, P. (2005). Miskonsepsi dan perubahan konsep dalam pendidikan fisika. Jakarta: Grasindo.

Trindade, J., Fiolhais, C., \& Almeida, L. (2002). Science learning in virtual environments: $A$ descriptive study. Oxford: Blackwell Publishers Ltd. 